TURIZAM

Volume 25 , Issue 3

$149-160(2021)$

ORIGINAL

SCIENTIFIC PAPER

\section{Correlation of Implementation of Principles and Functions of Management in Hospitality Business}

\author{
Natalija Knežević ${ }^{A}$, Biljana Grubor ${ }^{B}$, Bojana Kalenjuk', \\ Stefan Šmugović ${ }^{A}$, Maja Banjac ${ }^{A}$, Goran Radivojević ${ }^{A}$ \\ Received: January 2021 | Accepted: September 2021 \\ DOI: 10.5937/turizam25-33118
}

\begin{abstract}
Hospitality organizations of today keep up with the trends to remain competitive in a changeable market. For that reason, organizations must continuously work on their development and sustainability, and quality and good management is a precondition for successful business operations. Management is a universal process implemented in different production and service activities of the economy and different organizations regardless of the size and structure. Accordingly, food and beverage managers in hospitality have a task to combine fundamental principles and functions of management to achieve the company goals and bring success to the business. The subject of this paper is a review of principles and functions of management with the aim to make a correlation between individual functions and principles and their codependence in a restaurant business.
\end{abstract}

Keyword: food and beverage management, hospitality, restaurant business, management principles, management functions

\title{
Introduction
}

Hospitality management, whose aim is a successful business, requires specific knowledge and a unique set of skills (Tews, Van Hoof, 2011). Hospitality companies and their management are unprepared to respond to market demands. It is estimated that about a quarter of all restaurants end their business in the first year since the foundation, primarily because there is not an adequate business plan. For that reason, the focus is on an educated management staff versed in all its functions (Parsa et al., 2005; Tews, Van Hoof, 2011; Gunes et al., 2012).

When we talk about the definition of management, we cannot set a universal one, but different formulations of this term occur. Each author sets a different definition, but the essence always remains the same. One of the authors has defined management as an achievement

A University of Novi Sad, Faculty of Sciences, Department of Geography, Tourism and Hotel Management, Trg Dositeja Obradovića 3, 21000 Novi Sad, Serbia

B Hospitality and Tourism Stuff School, Jug Bogdanova 28, 11000 Belgrade, Serbia

Corresponding author: natalija.knezevic97@gmail.com 
of organizational goals efficiently and effectively by planning, organizing, leading, and controlling organizational resources (Daft, 2008). This definition will further serve as a basis for an analysis of managerial functions.

The development of management is crucial for business success, primarily profitability and productivity. Any deficiencies in the field of management will reduce competitiveness in the market, leading to lagging behind other companies (Li et al., 2013). The hospitality industry creates a recognizable context within which management develops. Intangibility, inseparability, and perishability characterize a service-based industry, and these characteristics demand a different management approach (Bowen, Ford, 2004; Cooper et al., 2008; Gagić et al., 2014).

The subject of this paper is the implementation of principles and functions of management in hospitality facilities. The task of this paper is to examine if there is a correlation between certain principles and functions. This paper aims to obtain data on a correlation between functions and principles of management and individual elements within each of them directed at the management of restaurants in the territory of Novi Sad.

For this reason, the following hypotheses were set for the purposes of this research:

$\mathrm{H}_{1}$ : Managers who implement the function of planning also control the business operations.

$\mathrm{H}_{2}$ : The organizational structure is clearly defined in hospitality facilities where a division of labor is established.

$\mathrm{H}_{3}$ : Employees are willing to follow those managers who have established their authority.

$\mathrm{H}_{4}$ : Managers who motivate their employees are willing to fairly reward them and organize training and education.

$\mathrm{H}_{5}$ : More motivated employees are more willing to act upon the instructions of theirsuperiors.

\section{Literature review}

\section{Principles of management}

With the aim to perceive all principles of management as important for the research, Table 1 shows their review and definitions of representative researchers in this field.

Table 1. Principles of management

\begin{tabular}{|c|c|c|c|}
\hline $\begin{array}{l}\text { ORDINAL } \\
\text { NUMBER }\end{array}$ & PRINCIPLE & DEFINITION & AUTHORS \\
\hline 1 & Division of work & $\begin{array}{l}\text { - division of labor } \\
\text { - } \text { specialization } \\
\text { - Employees are given tasks according to their expertise }\end{array}$ & Uzuegbu, Nnadozie, 2015 \\
\hline 2 & $\begin{array}{l}\text { Authority and } \\
\text { responsibility }\end{array}$ & $\begin{array}{l}\text { - } \text { authority of managers over subordinates } \\
\text { - } \text { responsibility of managers for their actions } \\
\text { ensure that activities are performed }\end{array}$ & Uzuegbu, Nnadozie, 2015 \\
\hline 3 & Discipline & $\begin{array}{l}\text { - clearly defined rules and regulations } \\
\text { - achieving good discipline and obedience of employees }\end{array}$ & Uzuegbu, Nnadozie, 2015 \\
\hline 4 & Unity of command & $\begin{array}{l}\text { - orders and commands come only from one source } \\
\text { - Employees are issued orders and commands only by } \\
\text { their superiors }\end{array}$ & Uzuegbu, Nnadozie, 2015 \\
\hline 5 & Unity of management & - One plan and one manager for each group of activities & Rodrigues, 2001 \\
\hline
\end{tabular}




\begin{tabular}{|c|c|c|c|}
\hline $\begin{array}{l}\text { ORDINAL } \\
\text { NUMBER }\end{array}$ & PRINCIPLE & DEFINITION & AUTHORS \\
\hline 6 & $\begin{array}{l}\text { Subordination } \\
\text { of individual and } \\
\text { organizational goals. }\end{array}$ & $\begin{array}{l}\text { - sacrificing personal interest for the benefit of the } \\
\text { organization } \\
\text { - organizations should not tolerate the lack of } \\
\text { commitment of employees }\end{array}$ & Uzuegbu, Nnadozie, 2015 \\
\hline 7 & $\begin{array}{l}\text { Rewarding the } \\
\text { personnel }\end{array}$ & $\begin{array}{l}\text { - Fair and realistic rewarding of employees for the work } \\
\text { done. } \\
\text { - Reasonable compensation for the job done } \\
\text { - Rewarding as additional motivation } \\
\text { Rewarding without underestimating and overestimating } \\
\text { abilities of employees }\end{array}$ & Rodrigues, 2001 \\
\hline 8 & (De)Centralization & $\begin{array}{l}\text { - the top management makes decisions and gives orders } \\
\text { - decisions go directly to all parts of the organization - } \\
\text { centralization } \\
\text { Decisions go indirectly through lower levels of } \\
\text { management - decentralization }\end{array}$ & Wren et al., 2002 \\
\hline 9 & Chain of hierarchy & $\begin{array}{l}\text { - only vertical organizational communication } \\
\text { - the emphasis is on the chain of authority }\end{array}$ & Uzuegbu, Nnadozie, 2015 \\
\hline 10 & $\begin{array}{l}\text { Material and } \\
\text { organizational order }\end{array}$ & $\begin{array}{l}\text { - all employees and all elements must be in their own } \\
\text { places }\end{array}$ & Tešanović, 2015 \\
\hline 11 & Equality & $\begin{array}{l}\text { - mutual fairness and honesty between superiors and } \\
\text { employees }\end{array}$ & Uzuegbu, Nnadozie, 2015 \\
\hline 12 & $\begin{array}{l}\text { Permanence of the } \\
\text { employed workers }\end{array}$ & $\begin{array}{l}\text { - continuous employment of the staff, without frequent } \\
\text { fluctuations }\end{array}$ & Tešanović, 2015 \\
\hline 13 & Initiative & $\begin{array}{l}\text { - managers should be creative } \\
\text { - managers should initiate new ideas }\end{array}$ & Uzuegbu, Nnadozie, 2015 \\
\hline 14 & Esprit de corps & - enthusiasm and harmony rule in the entire company & $\begin{array}{l}\text { Uzuegbu, Nnadozie, } 2015 \\
\text { Šmugović et al., } 2020\end{array}$ \\
\hline
\end{tabular}

\section{Functions of management}

Planning. It represents decision-making in advance - what, when, who, and how to perform a task. The first step of planning is to determine the goals of the organization, then the activities that will enable the achievement of these goals; then the next step is to assess the position of the organization according to the set goals (possibility of realization) and finally to delegate responsibilities to employees for performing a task (Shinde, 2018). In the following text, the plans of crucial significance for a profitable and successful business, which directly concern a manager of a hospitality facility, will be more clearly presented.

- Planninga production. In hospitality, production is based on the preparation of food and beverages which require more complex preparation. It takes place in the kitchen area and is based on the menu, which in hospitality represents a production plan composed on a daily, monthly, and yearly level (Tešanović, 2015; Roganović et al., 2019).

- Planning of supply. The principles of sustainable procurement of food are based on: local sources of raw materials, menu designs with a detailed emphasis on ingredients to raise awareness of consumed products, establishing steps for reducing the cost of ingredients, cooperation with suppliers, and care about the environment (Lehtinen, 2012; Cerutti et al., 2016; Bryan, Middlecamp, 2017). 
- Planning of occupancy of the capacity. This plan is based on dealing with the problems of using the capacity of the restaurant to maximize revenues, given that the unfilled capacity in the restaurant represents a lost income (Heo, 2017). The capacity represents the largest possible quantity of products in a given period with a predetermined number of employees, equipment, and size of space. This includes the kitchen area, staff, parking places as well as the size and layout of tables (Heo, 2017).

Organization. When the position of every employee is clearly defined, based on previous planning, which is directly connected with the function of the organization, a manager has a task to transform the plans into work tasks where the first step is to organize work by delegating tasks, responsibilities, and authority for individual employees from the predetermined organizational structure (Dessler, Philips, 2008; Odeny et al., 2020). The function of the organization is best seen through the definition of organizational structure and through delegating responsibilities to employees.

Leadership. Modern organizations which tend to increase the productivity and creativity of employees use leadership as a means to direct and facilitate activities. Unlike traditional management with the expressed hierarchical approach to control, in leadership, the accent is on the motivation of employees to increase their performance and realize the goals (Amabile et al., 2004; Khan, 2020). There are three implementable leadership styles: the autocratic style, the democratic style, and the liberal style (Kunnanatt, 2007).

Control. This function can be defined as formal procedures and systems that use the information for maintenance and changing forms or patterns of organizational activities (Henri, 2006).

Internal control is most often associated with the accounting domain and efforts to protect assets and ensure accounting records (Frazer, 2016). External control in hospitality besides sanitary, financial, tax, and other inspections, more and more often includes a modern way of checking, which is a mystery shopper, that is a mystery guest in this case. Namely, a mystery guest is a technique of anonymous observation. He or she must be well trained and should provide feedback on the quality of service (food and beverages) and the quality of serving staff (Liu et al., 2014).

Different kinds of control can be used in hospitality:

- Cost control. When we talk about ingredients and beverages, there are two methods of control: the factor method and the percentage method (Miller et al., 2002).

- Sales control. There are three principles to follow when controlling sales: optimization of the number of guests, profit increase and income control.

- Capacity utilization control. It is nothing but the so-called revenue management that deals with demand and the development of methodologies and systems of work for such a business and is becoming a necessary strategic tool in the service sector with limited capacities. It aims to assign the right table to the right guest and the right time. On the other hand, it represents an excellent tool for controlling the sales. RevPash, that is income per free hour of the seat, which is calculated as the quotient of a given time interval and the number of available seats in a given time (Kimes, Thompson, 2004; Heo, 2013).

Staff. In the recent literature, the fifth function appears more and more often, and that is personnel. The purpose of this function is the opportunity to recruit and select potential employees and thus expand the human potential of the company (Cooke et al., 2020; Colović et al., 2021). Important items are: 
- Training. Participation in a training program can enable employees to feel motivated and privileged because, in this way, they improve their knowledge and skills and thus perform activities more efficiently with improved performances and without professional deficiencies. The training also involves the social, physical, and mental development of individuals (Ozkeser, 2019). Organization of training can be performed by using methods such as role-playing, simulation exercises, or case studies. On the other hand, we should not forget the training during work, which often occurs in situations such as the arrival of new employees, as well as the introduction of new procedures, regulations, and similar (Tabassi, Bakar, 2008).

- Motivation. It represents an inner state which drives and provides energy, activates, and directs behavior towards goals. A motive cannot be seen, but we can see behavior caused by motives that can be interior or exterior (Goyal, 2015). When employees feel that they are justly and adequately rewarded for their efforts, engagements, loyalty, and enthusiasm with financial or non-financial incitements, they remain motivated and work productively; otherwise, they become unmotivated (Ahmad et al., 2010).

- Rewarding. This element of the personnel function includes financial (salaries, bonuses, and benefits) and non-financial rewards (Bonsdorff, Moilanen, 2005).

\section{Research methodology}

The research was conducted in 43 hospitality facilities in the territory of the hospitality and tourism center of Novi Sad. The respondents were employees working at different positions in the service and production sector, and their task was to evaluate the work of their manager. The obtained data were processed using descriptive analysis and correlation methods using the Pearson linear coefficient, which represents the strength and direction of a linear relationship between two variables (Pallant, 2009).

The research included 137 respondents, from which 95 questionnaires were completed by employees from different hospitality facilities. The survey was anonymous and on a voluntary basis, and the questions focused on basic managerial principles and functions in order to gain a real insight into their practical implementation.

\section{Results and discussion}

\section{The structure of respondents and the description of the sample}

In the research part, after analysing the sample and data on managers, the correlations of individual variables were determined. Variables refer to principles and functions of management and their co-dependence.

Table 2 shows the socio-demographic characteristics of the respondents, which indicate that the research included $66.3 \%$ of male employees, a maximum of $36.8 \%$ of employees at the position of waiters, where the largest share of $44.2 \%$ has work experience of one to five years in the current company. Regarding the type of hospitality facilities where the respondents are employed, the largest share belongs to a la cart restaurants $-70.5 \%$, whereas the largest share of restaurants has the capacity of more than 100 seats $-51.6 \%$. 
Table 2. Structure of participants ( $n=95)$

\begin{tabular}{|c|c|c|c|}
\hline Variable & Item & $\mathrm{N}$ & Share (\%) \\
\hline \multirow{2}{*}{ Gender } & Male & 63 & 66.3 \\
\hline & Female & 32 & 33.7 \\
\hline \multirow{4}{*}{ Work position } & Waiter/Waitress & 35 & 36.8 \\
\hline & Chef/Pastry & 23 & 24.2 \\
\hline & Bartender & 17 & 17.9 \\
\hline & Other & 20 & 21.1 \\
\hline \multirow{4}{*}{$\begin{array}{l}\text { Working experience in the } \\
\text { current restaurant/hotel }\end{array}$} & Less than one year & 40 & 42.1 \\
\hline & Between one and five years & 42 & 44.2 \\
\hline & Between five and ten years & 9 & 9.5 \\
\hline & More than ten years & 4 & 4.2 \\
\hline \multirow{4}{*}{$\begin{array}{l}\text { Type of a facility employee } \\
\text { works }\end{array}$} & A la carte restaurant & 67 & 70.5 \\
\hline & Guest house/Hotel & 4 & 4.2 \\
\hline & Fast food & 4 & 4.2 \\
\hline & Other & 20 & 21.1 \\
\hline \multirow{4}{*}{$\begin{array}{l}\text { Capacity of the hospitality } \\
\text { facility employee works }\end{array}$} & Less than 30 seats & 7 & 7.4 \\
\hline & Between 31 and 50 seats & 8 & 8.4 \\
\hline & Between 51 and100 seats & 31 & 32.6 \\
\hline & More than 100 seats & 49 & 51.6 \\
\hline
\end{tabular}

Source: Authors' calculations

Based on the obtained data, we can see in Table 3 that the largest share of managers are of the male gender $(78.9 \%)$ and that the majority of managers are between 26 and 35 years old (48.4\%), with work experience as managers of one to five years $(52.6 \%)$. The analysis of the education of managers gave the following structure: $42.1 \%$ of managers have secondary education, and $78.9 \%$ of respondents said that their manager did not finish a vocational school in the field of hospitality.

Table 3. Food and baverage managers strucure $(n=95)$

\begin{tabular}{|l|l|c|c|}
\hline Variable & Item & N & Share (\%) \\
\hline \multirow{4}{*}{ Gender } & Male & 75 & 78.9 \\
\cline { 2 - 4 } & Female & 20 & 21.1 \\
\hline \multirow{5}{*}{ Age } & Less than 25 years old & 7 & 7.4 \\
\cline { 2 - 4 } & Between 26 and 35 years old & 46 & 48.4 \\
\cline { 2 - 4 } & Between 36 and 45 years old & 24 & 25.3 \\
\cline { 2 - 4 } & Between 46 and 55 years old & 18 & 18.9 \\
\cline { 2 - 4 } & More than 55 years old & 0 & 0 \\
\hline \multirow{5}{*}{ Level of education } & High school & 40 & 42.1 \\
\cline { 2 - 4 } & High school & 23 & 24.2 \\
\cline { 2 - 4 } & Bachelor degree & 3 & 30.5 \\
\cline { 2 - 4 } & Master or PhD degree & 29 & 3.2 \\
\hline
\end{tabular}




\begin{tabular}{|l|l|c|c|}
\hline Variable & Item & N & Share (\%) \\
\hline \multirow{2}{*}{$\begin{array}{l}\text { Degree oriented to } \\
\text { hospitality industy }\end{array}$} & Yes & 20 & 21.1 \\
\cline { 2 - 4 } & No & 75 & 78.9 \\
\hline \multirow{4}{*}{ Working experience } & Less than one year & 11 & 11.6 \\
\cline { 2 - 4 } & Between one and five years & 50 & 52.6 \\
\cline { 2 - 4 } & Between five and ten years & 22 & 23.2 \\
\cline { 2 - 4 } & More than ten years & 12 & 12.6 \\
\hline
\end{tabular}

Source: Authors' calculations

The analysis of the correlation between the planning fuction and the control function

The correlation in this part of research primarily refers to the relationship of variables of planning and control functions. The obtained results aimed to show the correlation between the frequency of planning the menu/drink list and the production control. We found that the correlation between these two variables $r=0.28, n=95$ is weak and positive, with the frequency of planning the menu/drink list (production) follows the increased production control (Table 4).

Table4. The correlation between the menu planning and the production control $(n=95)$

\begin{tabular}{|c|c|c|}
\hline & Menu planning & Production control \\
\hline Menu planning & 1 & \\
\hline Production control & $.281^{*}$ & 1 \\
\hline
\end{tabular}

${ }^{*} p<0,05$; Source: Authors' calculations

Here, we include the third variable - the normative control and its relationship with planning the menu/drink list. The obtained values $r=0.36, n=95$ indicate a moderate positive correlation, where the frequency of planning the menu/drink list (production) follows the increased control of normative (Table 5).

Table 5. The correlation between the menu planning and the normative control $(n=95)$

\begin{tabular}{|c|c|c|}
\hline & Menu planning & Normative control \\
\hline Menu planning & 1 & \\
\hline Normative control & $.358^{*}$ & 1 \\
\hline
\end{tabular}

${ }^{*} p<0,05$; Source: Authors' calculations

The following correlation refers to optimal supply and control of procurement. The obtained data indicate the relationship between these two variables, which is moderate and positive, because $r=0.39, n=95$, meaning that the managers who correctly plan the procurement to be optimal control it (Table 6).

Table 6. The correlation between the optimal supply and the control of procurement $(n=95)$

\begin{tabular}{|c|c|c|}
\hline & Optimal supply & Control procurement \\
\hline Optimal supply & 1 & \\
\hline Control procurement & $.390^{*}$ & 1 \\
\hline
\end{tabular}

${ }^{*} p<0,05$; Source: Authors' calculations 
The correlation between planning and proportionality of the number of employees concerning the scope of work and control of work of the serving staff calculated based on parameters where $r=0.60, n=95$ is positive and very strong, meaning that the managers who plan a proportionate number of employees concerning the scope of work control the work of the employees (Table 7).

Table 7. The correlation of the staff planning in comparison to the scope of work and the staff control $(n=95)$

\begin{tabular}{|c|c|c|}
\hline & $\begin{array}{c}\text { Proportionality of the } \\
\text { number of employees }\end{array}$ & Staff control \\
\hline $\begin{array}{c}\text { Proportionality of the } \\
\text { number of employees }\end{array}$ & 1 & \\
\hline Staff control & $.600^{*}$ & 1 \\
\hline
\end{tabular}

${ }^{*} p<0,05$; Source: Authors' calculations

The obtained results of the correlation prove that the managers who base their business on planning also apply the control function, which confirms the theoretical principles that there is a strong relationship between planning and control and that these two managerial functions cannot do without each other.

\section{The analysis of correlation between principles and functions of management}

The second part of the research refers to the relationship of certain principles and functions of management, that is, variables of different and the same functions.

The correlation between the definition of labor division and organizational structure is negative and moderate because $\mathrm{r}=0.37, \mathrm{n}=95$, meaning that the set division of labor within restaurants does not necessarily follow the defined organizational structure (Table 8).

Table 8. The correlation between the definition of labor and the organizational structure ( $n=95)$

\begin{tabular}{|c|c|c|}
\hline & Definition of labor & $\begin{array}{c}\text { Organizational } \\
\text { structure }\end{array}$ \\
\hline Definition of labor & 1 & \\
\hline $\begin{array}{c}\text { Organizational } \\
\text { structure }\end{array}$ & $-.374^{*}$ & 1 \\
\hline
\end{tabular}

${ }^{*} p<0,05$; Source: Authors' calculations

The relationship between the existence of authority of managers and establishing discipline and the willingness of employees to follow instructions of the managers resulted as a positive and moderate correlation, where $r=0.41, n=95$, which implies that the more authority and discipline, the greater willingness of employees to follow instructions they receive from their managers (Table 9). 
Table 9. The correlation between the authority and the established discipline and the employees' willingness to follow instructions ( $n=95)$

\begin{tabular}{|c|c|c|}
\hline & $\begin{array}{c}\text { Authority and } \\
\text { discipline }\end{array}$ & Following instructions \\
\hline $\begin{array}{c}\text { Authority and } \\
\text { discipline }\end{array}$ & 1 & \\
\hline Following instructions & $.414^{*}$ & 1 \\
\hline
\end{tabular}

${ }^{*} p<0,05$; Source: Authors' calculations

\section{The analysis of the correlation between different functions of management}

The third part of the research aims to examine whether managers, that is leaders, who motivate their employees also realistically and fairly reward them. The calculation shows a strong and positive correlation between these two variables with parameters $r=0.56, n=95$, where the high commitment of managers to motivate their employees is accompanied by realistic and fair rewards (Table 10).

Table 10. The correlation between the employees' motivation and the rewards $(n=95)$

\begin{tabular}{|c|c|c|}
\hline & $\begin{array}{c}\text { Employees' } \\
\text { motivation }\end{array}$ & Rewards \\
\hline Employees' motivation & 1 & \\
\hline Rewards & $.560^{*}$ & 1 \\
\hline
\end{tabular}

${ }^{*} p<0,05$; Source: Authors' calculations

Calculating the values regarding whether managers who are committed to motivating their employees organize training and education, a positive and moderate correlation was observed, with $r=0.39, n=95$, where managers who are focused on motivating their employees more often opt for organizing training and education for their employees (Table 11).

Table 11. The correlation between the employees' motivation asn the organizing trainings and education $(n=95)$

\begin{tabular}{|l|c|c|}
\hline & $\begin{array}{c}\text { Employees' } \\
\text { motivation }\end{array}$ & Traning and education \\
\hline Employees' motivation & 1 & 1 \\
\hline Traning and education & $.388^{*}$ & 1 \\
\hline
\end{tabular}

${ }^{*} p<0,05$; Source: Authors' calculations

\section{The analysis of the correlation between variables within functions of management}

The last correlation also refers to managers' focus on motivating their employees and the willingness of the employees to follow instructions of the managers. The obtained values are $\mathrm{r}=0.69, \mathrm{n}=95$, which represents a strong and positive correlation. It means that employees are mostly willing to follow instructions they receive from their superiors if their manager works to improve the motivation of their subordinates (Table 12). 
Table 12. The correlation between the employees' motivation and their willingness to follow instructions $(n=95)$

\begin{tabular}{|c|c|c|}
\hline & $\begin{array}{c}\text { Employees' } \\
\text { motivation }\end{array}$ & $\begin{array}{c}\text { Employees' } \\
\text { willingness to follow } \\
\text { instructions }\end{array}$ \\
\hline Employees' motivation & 1 & 1 \\
\hline $\begin{array}{c}\text { Employees' willingness } \\
\text { to follow instructions }\end{array}$ & $.689^{*}$ & \\
\hline
\end{tabular}

${ }^{*} p<0,05$; Source: Authors' calculations

\section{Conclusion}

Based on the conducted research, we can observe that there are more or less strong correlations between certain principles and functions, as well as correlations within individual functions. Certain functions of management are co-dependent - the presence of one demands the presence of the other, therefore to do business successfully, managers must be prepared to master all the functions and find the best mechanism to combine and master them.

Analyzing the obtained results, we concluded that the managers who formulate plans for individual activities (production, procurement, cost, and employees) control the set plans, which confirms the first hypothesis.

The research has shown that in hospitality facilities where there is a clearly defined division of labor, the organizational structure of employees need not be specified. According to the obtained results, the second hypothesis is rejected because it claims that the division of labor is conditioned with the existence of a clear organizational structure.

The third set hypothesis of the research is that the employees are willing to follow those managers who have established their authority, which is confirmed. A greater authority that employees see in their superiors causes greater willingness of employees to follow them.

The fourth hypothesis claims that managers who motivate their employees are willing to fairly reward them and organize training and educations, which the obtained results confirm. Analyzing the results, we can observe a correlation of a positive direction and moderate intensity, implying that the managers who are focused on motivating their employees emphasize fair rewards and organize training and education for their employees.

The last, the fifth, hypothesis states that more motivated employees follow instructions of their superiors to a large extent. This hypothesis is confirmed because the greater motivation of the employees, the more agile they are to follow and accept instructions.

\section{Acknowledgements}

The authors acknowledge financial support of the Ministry of education, Science and Technological Development of the Republic of Serbia (Grant No. 451-03-9/2021-14/200125). 


\section{References}

Ahmad, S., Mukaddes, A. M., Rashed, C. A., Samad, M. A. 2010. Implementation of motivation - Theory in apparel industry. International Journal of Logistics and Supply Chain Management 103-108.

Amabile, T. M., Schatzel, E. A., Moneta, G. B., Kramer, S. J. 2004. Leader behaviours and the work environment for creativity: Perceived Leader Support. The Leadership Quarterly 15(1), 5-32.

Bonsdorff, M., Moilanen, R. 2005. Rewarding Ageing Employees-Means Used in the Bublic Sector. International Congress Series 1280, 409-414.

Bowen, J., Ford, R. C. 2004. What experts say about managing hospitality service delivery system. International Journal of Contemporary Hospitality Management 16(7), 394-401.

Bryan, T. W., Middlecamp, C. H. 2017. Learning Through Eating: Bringing Campus Dining Operations Into an Environmental Science Course. Sustainability 10(1), 30-38.

Cerutti, A. K., Contu, S., Ardente, F., Donno, D., Beccaro, G. L. 2016.Carbon Footprint in Green Public Procurement: Policy Evaluation From a Case Study in the Food Sector. Food Policy $58,82-93$.

Čolović, M., Nikić, G., Stamatović, M. 2021. The relation between gender and differences in emotional intelligence of female managers in modern rural tourism. Ekonomika poljoprivrede 68(1), 69-83.

Cooke, F. L., Schuler, R., Varma, A. 2020. Human Resource Management Research and Practice in Asia: Past, Present and Future. Human Resource Management Review 30, 1-13.

Cooper, C., Fletcher, J., Fyall, A., Wanhill, S. 2008. Tourism: Principles and practice. Financial Times/Prentice Hall, Harlow, England.

Daft, R. 2008. Management. Thomson, Toronto.

Dessler, G., Philips, J. 2008. Managing Now. Houghton Mifflin Company, Boston.

Frazer, L. 2016. Internal Control: Is it a Benefit or Fad to Small Companies? A Literature Dependency Perspective. Journal of Accounting and Finance16 (4), 149-161.

Gagić, S., Tešanović, D., Kalenjuk, B. 2014. Improvement of business performance in restaurants using innovation strategies. Turističko poslovanje (14), 91-99.

Goyal, P. K. 2015. Motivation: Concept, Theories and Practical implications. International Research Journal of Commerce Arts and Science 6, 71-78.

Gunes, G., Karakoc, G., Bastemur, C. 2012. Integration of environmental aspects in tourism higher education: The hotel managers' point of view. Turizam 16(4), 152-169.

Henri, J. F. 2006. Management Control Systems and Strategy: A Resource-based Perspective. Accounting, Organizations and Society 31 (6), 529-558.

Heo, C. Y. 2017. New Performance Indicators for Restaurant Revenue Management: ProPASH and ProPASM. International Journal of Hospitality Management 61, 1-3.

Heo, C.Y., Lee, S., Mattila, A., Hu, C. 2013. Restaurant revenue management: Do perceived capacity scarcity and price differences matter? International Journal of Hospitality Management 35, 316-326.

Khan, I. U., Khan, M. S., Idris, M. 2020. Investigating the Support of Organizational Culture for Leadership Styles (transformational \& transactional). Journal of Human Behavior in the Social Environment 1-12.

Kimes, E. S., Thompson, M. G. 2004. Restraurant Revenue Management at Chevys: Determing the Best Table Mix. Decision Science 35, (3), 371-392. 
Kunnanatt, J. T. 2007. Leadership Orientation of Service Sector Managers in India: An Empirical Study. Business and Society Review 112(1), 99-119.

Lehtinen, U. 2012. Sustainability and Local Food Procurement: A Case Study of Finnish Public Catering. British Food Journal 114(8), 1053-1071.

Li, L., Gray, D. E., John Lockwood, A., Buhalis, D. 2013. Learning About Managing the Business in the Hospitality Industry. Human Resource Development Quarterly 24(4) 525-559.

Liu, C. H. S., Su, C. S., Gan, B., Chou, S. F. 2014. Effective restaurant rating scale development and a mystery shopper evaluation approach. International Journal of Hospitality Management 43, 53-64.

Miller, J., Hayes, D., Dopson, L. 2002. Food and Beverage Cost Control. John Wiley\&Sons, Inc., New York.

Odeny, J. A., Maingi, S., Kurauka, J. 2020. The role of procurement procedures in environmental management: A case study of classified hotels in Mombasa County, Kenya. Menadžment $u$ hotelijerstvu $i$ turizmu 8(1), 11-23.

Ozkeser, B. 2019. Impact of Training on Employee Motivation in Human Resources Management. Procedia Computer Science 158, 802-810.

Pallant, J. 2009. SPSS Manual:A Step by Step Guide to Analysis Using SPSS for Windows (Version 15), $3^{\text {rd }}$ Edition. Mikroknjiga, Belgrade.

Parsa, H.G., Self, J.T., Njite, D., King, T. 2005. Why restaurants fail. Cornell Hotel and Restaurant Administration Quarterly 46, 304-322.

Rodrigues, C. A. 2001. Fayol's 14 Principles of Management then and now: a Framework for Managing Today's Organizations Effectively. Management Decision 39, 880-889.

Roganović, J., Kalenjuk, B., Grubor, B., Radivojević, G., Ćirić, M. 2019. The application of standard operating procedures in hospitality in the territory of the city of Novi Sad. Zbornik radova Departmana za geografiju, turizam $i$ hotelijerstvo 48(2), 174-184.

Shinde, S. 2018. Functions of Management. Lulu Publication. Releigh, USA.

Šmutović, S., Kalenjuk, B., Grubor, B. 2020. Satisfaction with working conditions of employees in restaurants in Novi Sad. Turističko poslovanje (25-26), 5-15.

Tabassi, A. A., Bakar, A. A. H. 2008. Training, motivation, and performance: The case of human resource management in construction projects in Mashhad, Iran. International Journal of Project Management 28, 471-480.

Tešanović, D. 2015. Gastronomy Management. The College of Hotel Management, Belgrade. (In Serbian)

Tews, M., Van Hoof, H. 2011. In Favor of Hospitality - Management Education. Hospitality Review 29 (2), 121-129.

Uzuegbu, C. P., Nnadozie, C. O. 2015. Henry Fayol's 14 Principles of Management: Implications for Libraries and Information Centeres. Journal of Information Science Theory and Practice 3, 58-72.

Wren, D. A., Bedeian, A. G., Breeze, J. D. 2002. The Foundations of Henri Fayol's Administrative Theory. Management Decision 40, 906-918. 